\title{
Hybrid Immune Response to Parental Liver Tissue Grafts
}

\author{
Jane S. Schultz ${ }^{1,2}$, Roberta DeMott-Friberg ${ }^{1}$, and Theodore F. Beals ${ }^{1,3}$ \\ ${ }^{1}$ VA Medical Center, Ann Arbor, Michigan \\ ${ }^{2}$ Department of Human Genetics and ${ }^{3}$ Department of Pathology, University of Michigan, Ann Arbor, \\ Michigan
}

\begin{abstract}
Parental-to- $\mathrm{F}_{1}$-hybrid liver tissue grafts in like-sex donor-recipient combinations survive indefinitely, although several $F_{1}$ recipients demonstrate an immunological response to the parental graft. Female $F_{1}$ recipients, particularly those carrying the $H-2^{b}$ haplotype, respond vigorously to male parental liver grafts. However $F_{1}$ female responses to male parental liver tissue grafts differ substantively from the responses of parental females to syngeneic male grafts. $\mathrm{C} 3 \mathrm{H}$ male liver grafts are rejected vigorously by $\mathrm{F}_{1}$ females as long as the $\mathrm{F}_{1}$ carries the $\mathrm{H}-2^{b}$ haplotype. These findings support previous reports of strong immunological responses to $\mathrm{C} 3 \mathrm{H} \mathrm{H}-\mathrm{Y}$ antigen in female $\mathrm{F}_{1}$ and $\mathrm{C} 3 \mathrm{H}$.SW animals, a response which is absent in $\mathrm{C} 3 \mathrm{H}$ females. Female $\mathrm{F}_{1}$ hybrids carrying the $H-2^{b}$ haplotype do not reject grafts of $\mathrm{B} 10$ or $\mathrm{B} 6$ male liver as rapidly as do $\mathrm{B} 10$ or $\mathrm{B} 6$ parental females. This reduced $\mathrm{F}_{1}$ response may be related to the formation of hybrid antigens and consequent alteration of the anti-H-Y response. Alternatively, cells that specifically suppress the anti-H-Y response may be present in $F_{1}$ hybrids. Factors responsible for suppression appear to be controlled by non-MHC antigens, at least in $(\mathrm{C} 3 \mathrm{H} \times \mathrm{B} 6$ or $\mathrm{B} 10) \mathrm{F}_{1}$ hybrids.
\end{abstract}

\section{Introduction}

It is generally expected that syngeneic grafts (within an inbred strain) or grafts from either parental strain to an $F_{1}$ hybrid of those strains will be permanently accepted. However, $F_{1}$ hybrid responses to parental antigens have been reported in diverse systems. Cudkowicz and Bennett (1971) have shown that $F_{1}$ hybrid mice resist parental bone marrow grafts. Homozygous tumors grow better in syngeneic 
recipients than in their $F_{1}$ hybrids (Hellström 1964, Snell 1958). Eichwald and coworkers (1965) have demonstrated similar phenomena in parental-to- $F_{1}$ skin grafts. More recently Nakano and colleagues (1981) have shown that cytotoxic $\mathrm{T}$ lymphocytes against parental $\mathrm{H}-2$ antigens may be generated in $\mathrm{F}_{1}$ hybrids.

One exception to the rule of permanent survival of syngeneic grafts is the rejection of male grafts by females of the same strain due to the presence of the H-Y antigen on the donor tissue (reviewed by Gasser and Silvers 1972). Skin grafts from male mice to syngeneic recipient females are rejected when the animals carry the $K$ end of the $H-2^{b}$ haplotype, but not when $H-2^{b}$ is totally absent (Gasser and Silvers 1972). Parental male skin grafts to $F_{1}$ females are also rejected when one of the parental strains is $H-2^{b}$. Immune response to the H-Y antigen would seem to be under the control of the major histocompatibility complex (MHC).

Studies of survival of parental-to- $\mathrm{F}_{1}$ skin grafts indicate that qualitative or quantitative differences among strains exist in the expression of the H-Y antigen, which is controlled by a gene or genes residing on the $\mathrm{Y}$ chromosome. These differences may, in part, result from MHC effects (Silvers and Wachtel 1977). Recently, evidence has been reported for the existence of a second H-Y antigen controlled by an autosomal gene (Simpson et al. 1982).

Our interest in the similarities and differences of graft rejection phenomena in tissues other than skin or lymphocytes has led to a study of liver-graft rejection over the H-Y barrier (DeMott-Friberg et al. 1979). We have found that the strongest anti-H-Y response to liver tissue grafted onto a kidney bed is controlled by the $H-2^{b}$ haplotype. A weak immune response to $\mathrm{H}-\mathrm{Y}$ is found in female mice of strains carrying $H-2$ haplotypes other than $H-2^{b}$. Strangely, a strong anti-H-Y response is found in the SJL $\left(H-2^{s}\right)$ strain.

$\mathrm{F}_{1}$ females sometimes evoke a strong immune response to male liver grafts from parental strains other than the $H-2^{b}$ parent. Response to grafts from the $H-2^{b}$ parent may also be weaker than the response to grafts from the non- $H-2^{b}$ parent.

Several factors may be acting in $F_{1}$ hybrids to modify the response of female mice of the $H-2^{b}$ haplotype to grafts of male liver. The responses observed in these studies may be controlled by $\mathrm{H}-\mathrm{Y}$ antigenic variation, an immune response unique to $F_{1}$ hybrids, formation of hybrid antigens, or interaction between $T$-cell populations carrying different alleles at different $\mathrm{H}-2$ subregions.

\section{Material and Methods}

Mice. Mice of all inbred strains used in these experiments were obtained from the National Cancer Institute (NCI) except mice of the C3H.SW/Sn congenic strain, which were obtained from the Jackson Laboratory, Bar Harbor, Maine. $\mathrm{C} 57 \mathrm{BL} / 6 \times \mathrm{C} 3 \mathrm{H}\left(\mathrm{B}_{6} \mathrm{C}_{3} \mathrm{~F}_{1}\right)$ mice were obtained from NCI. All other $\mathrm{F}_{1}$ mice were bred in our mouse colony at the Ann Arbor VA Medical Center.

Grafting procedure and criteria for evaluation. The routine grafting procedure has been fully described previously (Schultz et al. 1976). In brief, a small piece of liver taken from an anesthesized donor is placed on the etherized recipient's left kidney, which has been prepared by removing a shallow subcapsular slice. The recipient's abdominal incision is sutured and the mouse returned to the animal colony. Although one donor can provide liver for all grafts of a series, usually several donors are used to control for possible autogenous results. Ten replicates of most donor recipient pairs were studied. However, in some cases there were as few as six or as many as eleven identical grafts performed. 
At predetermined time periods, the recipient mice are killed by cervical dislocation. Grafted kidneys are removed, fixed, trimmed, embedded, sectioned, and stained. Numerous sections of each grafted kidney are screened to locate the central area of the graft. Three slides containing sections from the most central areas of the graft are then evaluated independently by three persons.

Criteria for evaluation. Slides from replicate animals and serial time periods are evaluated on different days. Slides are examined without knowledge of the donor/recipient combinations, time period, or experiment to minimize subjective interpretations. A graft is first evaluated for rejection or survival by the presence of hepatocytes. The state of immunological reactivity of the host to the graft is judged by the quantity and nature (nodular or scattered) of lymphocytic infiltration, the quantity and physical state of fibrovascular tissue repopulating the graft (young and active or old and collagenized), the distribution of hepatocytes (well-organized as in a syngeneic graft, active and proliferating, or scattered and degenerating) and the appearance of the scar (newly formed or mature). Technical failures of grafts in this system are minimal and are easily distinguished from rejected grafts since hemosiderin laden macrophages mark the graft site. Photomicrographs of various immunological grades of graft have been published previously (DeMott-Friberg et al. 1979, Schultz et al. 1978).

The scoring system for evaluating graft-host interaction for minor loci (Schultz et al. 1978) was used. This system uses $\mathrm{P}$ to identify a proliferating graft with more than four layers of hepatocytes with or without cellular immunological activity, S to identify a syngeneic-like graft with 3-4 well-organized layers of hepatocytes with little or no celfular immunological activity, C-1 to identify a healthy graft with a few lymphocytes concentrated or in small nodules at the graft-bed interface, $\mathrm{C}-2$ to identify a graft containing less healthy, poorly organized hepatocytes with a considerable number of lymphocytes scattered throughout the graft, C-3 to identify a graft containing degenerating, scattered hepatocytes, copious lymphocytic infiltrate and fibrovascular tissue, C-4 to identify a graft with lymphocytes present in large nodules and with only a few scattered degenerating hepatocytes in a young scar, C-5 to identify a graft consisting of fibrovascular tissue with some collagen (young scar), a variable number of lymphocytes present and no hepatocytes and C-6 to identify a graft with only a matured (contracted) scar from which most lymphocytes have receded. The ultimate fate of a graft identified as C-6 is indistinguishable from that of an acutely rejected graft such as that seen across an $\mathrm{H}-2$ barrier.

Statistical analysis. The question of whether the immunological grades of grafts in any two donorrecipient combination are identical was determined by a goodness-of-fit test modified from Mood 1950, by Dr. R. Curl, Department of Chemical Engineering, University of Michigan. The goodness-of-fit test for the $r$ and $s$ contingency tables (at the $100 \%$ level of significance) is:

$$
\begin{aligned}
& \chi^{2}=2 \sum_{i=1}^{r} \sum_{j=1}^{s} f_{i j} \ln \frac{f_{i j}}{\Theta_{i} \tau_{j} N}>\chi^{2}(r-1)(s-1) ; \alpha \\
& \text { where } \sum_{i}^{r} \sum_{j}^{s} f_{i j}=N ; \theta_{i}=\frac{1}{N} \sum_{j=1}^{s} f_{i j} ; \tau_{j}=\frac{1}{N} \sum_{i=1}^{r} f_{i j}
\end{aligned}
$$

and $s=7$ immunological grades, $r=2$ donor-recipient combinations to be compared and $f_{i j}$ is the number of animals assigned a particular grade for a particular donor-recipient combination.

Immunological grade differences are of high significance $(p<.01)$, moderate significance $(.01<p$ $<.025)$ or low significance $(.025<p<.1)$. If the probability of two samples coming from the same population is greater than 0.1 , they are considered to be identical in immunological grades.

\section{Results}

The mean immunological reactivities of recipient female- $F_{1}$ 's-to-parental-male donor liver grafts are found in Table 1. Each of these means represents a weighted average. Proliferating grafts are given a weight of -3 and fully rejected grafts are given a weight of +3 . Each of the remaining grades is given a whole number weighting between -3 and +3 . Since proliferating grafts are possibly being 
enhanced, they are represented by a grade at the lowest end of the scale. Syngeneiclike grafts are weighted -2 since they show neither rejection nor enhancement. The increasing immunological activities rated $C-1$ to $C-5 / 6$ are weighted -1 to +3 . The mean grade is calculated by multiplying the number of animals with a particular rating by the weight for that rating, totalling all of the products for a particular combination, and dividing by the total number of grafted animals. The mean grades for each donor-recipient combination (parental-to- $F_{1}$ liver grafts for male-tofemale, female-to-female, male-to-male and female-to-male donors to recipients) are given in Table 1.

Donor-recipient combinations significantly different in immunological grade are shown in Tables $2 \mathrm{a}, \mathrm{b}$, and c. All other combinations analyzed are not statistically different.

Data in Table 2a compares results in graft combinations in which the $F_{1}$ recipients are identical but the donors differ. These differences are only significant in $a$ few cases. In Table $2 b$ data are given comparing results in graft combinations in which the donors are identical but the $\mathrm{F}_{1}$ recipients vary. In both Tables $2 \mathrm{a}$ and $2 \mathrm{~b}$ the donor and recipient combinations compared are of the same sex, i. e., a male-tofemale graft combination is compared with a male-to-female graft combination, eliminating sex differences. There are only a few significant differences when combinations are compared in which the donors are constant and the $\mathrm{F}_{1}$ recipients differ (Table 2b).

When donors and recipients are the same but the sex combinations differ, many highly significant differences among donor-recipient combinations are found (see Table 2c). This is true for all donors studied, but the extent of significance of the grade difference between any two donor recipient comparisons is dependent on whether $H-2^{b}$ is one of the $H-2$ alleles in the recipient, which parental strain is the

Table 1. Mean immunological reactivity of $F_{1}$ 's to parental grafts

\begin{tabular}{|c|c|c|c|c|c|}
\hline \multirow[t]{2}{*}{$F_{1}$ recipient } & \multirow[t]{2}{*}{ Donor } & \multicolumn{4}{|c|}{ Donor and recipient sex } \\
\hline & & $\delta \rightarrow q$ & $9 \rightarrow q$ & $\hat{0} \rightarrow \hat{O}^{*}$ & $q \rightarrow \hat{O}^{*}$ \\
\hline \multirow[t]{2}{*}{$\mathrm{B} 10 \times \mathrm{B} 6$} & B6 & $+3.0^{*}(9)^{\dagger}$ & $-1.6(10)$ & $-2.3(10)$ & $-2.2(9)$ \\
\hline & B10 & $+2.6(9)$ & $-1.7(10)$ & $-2.3(8)$ & $-2.1(11)$ \\
\hline \multirow[t]{2}{*}{ B10 × C3H.SW } & $\mathrm{B} 10$ & $+1.3(10)$ & $-1.5(10)$ & $-2.6(10)$ & $-2.5(10)$ \\
\hline & C3H.SW & $+3.0(10)$ & $-2.0(10)$ & $-2.4(10)$ & $-1.5(11)$ \\
\hline \multirow[t]{2}{*}{$\mathrm{B} 6 \times \mathrm{C} 3 \mathrm{H}$} & B6 & $-0.1(8)$ & $-1.6(8)$ & $\mathrm{ND}^{+}$ & $-1.3(6)$ \\
\hline & $\mathrm{C} 3 \mathrm{H}$ & $+3.0(8)$ & $-2.0(6)$ & ND & ND \\
\hline \multirow[t]{2}{*}{$\mathrm{B} 10 \times \mathrm{C} 3 \mathrm{H}$} & $\mathrm{B} 10$ & $+0.4(11)$ & $-1.3(9)$ & $-2.6(10)$ & $-2.0(11)$ \\
\hline & $\mathrm{C} 3 \mathrm{H}$ & $+2.7(11)$ & $-0.1(11)$ & $-2.8(11)$ & $-0.5(11)$ \\
\hline \multirow[t]{2}{*}{$\mathrm{DBA} / 2 \times \mathrm{B} 10$} & $\mathrm{~B} 10$ & $+0.1(8)$ & $-1.6(10)$ & $-2.8(8)$ & $-1.5(11)$ \\
\hline & $\mathrm{DBA} / 2$ & $-0.1(9)$ & $-1.8(8)$ & $-2.8(10)$ & $-2.8(10)$ \\
\hline \multirow[t]{2}{*}{$\mathrm{C} 3 \mathrm{H} \times \mathrm{DBA} / 2$} & $\mathrm{C} 3 \mathrm{H}$ & $-0.5(9)$ & $-1.3(4)$ & $-2.0(10)$ & $-1.9(10)$ \\
\hline & $\mathrm{DBA} / 2$ & $-1.3(11)$ & $-2.2(6)$ & $-2.1(10)$ & $-2.0(9)$ \\
\hline
\end{tabular}

\footnotetext{
* Immunological grade range $=-3$ to +3 , least reactivity to greatest reactivity.

$\dagger()=$ Number in group.

$¥ \mathrm{ND}$, No data.
} 
Table 2. Significant differences in liver graft survival between different combinations

\begin{tabular}{|c|c|c|c|}
\hline \multirow[b]{2}{*}{ Comparing } & \multicolumn{3}{|c|}{ Level of significance } \\
\hline & High & Medium & Low \\
\hline \multicolumn{4}{|l|}{ a. Identical $F_{1}$ recipients; different strain, like sex donors } \\
\hline $\mathrm{B} 63 \rightarrow(\mathrm{B} 6 \times \mathrm{C} 3 \mathrm{H})$ 早 and $\mathrm{C} 3 \mathrm{H} \jmath \rightarrow(\mathrm{B} 6 \times \mathrm{C} 3 \mathrm{H})$ ? & + & & \\
\hline $\mathrm{B} 6 \delta \rightarrow(\mathrm{B} 6 \times \mathrm{C} 3 \mathrm{H}) \%$ and $\mathrm{B} 103 \rightarrow(\mathrm{B} 10 \times \mathrm{C} 3 \mathrm{H})$ 早 & & + & \\
\hline 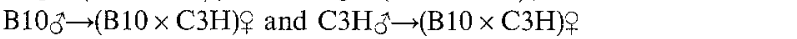 & & & + \\
\hline $\mathrm{B} 109 \rightarrow(\mathrm{B} 10 \times \mathrm{C} 3 \mathrm{H})$ ㅇ and $\mathrm{C} 3 \mathrm{H}_{+} \rightarrow(\mathrm{B} 10 \times \mathrm{C} 3 \mathrm{H}) \stackrel{+}{\circ}$ & & & + \\
\hline $\mathrm{B} 10_{+} \rightarrow(\mathrm{B} 10 \times \mathrm{C} 3 \mathrm{H}) \hat{s}$ and $\mathrm{C} 3 \mathrm{H}$ 우 $\rightarrow(\mathrm{B} 10 \times \mathrm{C} 3 \mathrm{H}) \lesssim$ & & & + \\
\hline \multicolumn{4}{|l|}{ b. $F_{1}$ like sex recipients differing in one parent; identical donors } \\
\hline $\mathrm{B} 10 \delta^{*} \rightarrow(\mathrm{B} 6 \times \mathrm{B} 10) \stackrel{9}{\rightarrow}$ and $\mathrm{B} 10 \delta^{*} \rightarrow(\mathrm{B} 10 \times \mathrm{C} 3 \mathrm{H}) \mathrm{P}$ & & & + \\
\hline $\mathrm{B} 6{ }_{3} \rightarrow(\mathrm{B} 6 \times \mathrm{B} 10)+$ and $\mathrm{B} 6 \hat{\circ} \rightarrow(\mathrm{B} 6 \times \mathrm{C} 3 \mathrm{H}) \stackrel{?}{?}$ & + & & \\
\hline $\mathrm{B} 10 \hat{0} \rightarrow(\mathrm{B} 6 \times \mathrm{B} 10)$, and $\mathrm{B} 10^{\wedge} \rightarrow(\mathrm{DBA} / 2 \times \mathrm{B} 10)$ ? & & & + \\
\hline $\mathrm{C} 3 \mathrm{H}_{\delta} \rightarrow(\mathrm{B} 10 \times \mathrm{C} 3 \mathrm{H})$ 웅 and $\mathrm{C} 3 \mathrm{H}_{5} \rightarrow(\mathrm{C} 3 \mathrm{H} \times \mathrm{DBA} / 2) 9$ & + & & \\
\hline $\mathrm{C} 3 \mathrm{H}_{\delta} \rightarrow(\mathrm{B} 6 \times \mathrm{C} 3 \mathrm{H})$ 우 and $\mathrm{C} 3 \mathrm{H}_{\delta} \rightarrow(\mathrm{C} 3 \mathrm{H} \times \mathrm{DBA} / 2)$ 웅 & + & & \\
\hline 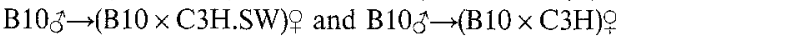 & & & + \\
\hline \multicolumn{4}{|l|}{$\begin{array}{l}\text { c. Donors of same strain, recipients of same strain- } \\
\text { sex difference in donor, recipient or both }\end{array}$} \\
\hline $\mathrm{B} 6 \sigma^{*} \rightarrow(\mathrm{B} 10 \times \mathrm{B} 6) \mathrm{q}$ and $\mathrm{B} 6 q \rightarrow(\mathrm{B} 10 \times \mathrm{B} 6)_{\mathrm{f}}$ & + & & \\
\hline $\mathrm{B} 6{ }^{*} \rightarrow(\mathrm{B} 10 \times \mathrm{B} 6)$ 車 and $\mathrm{B} 6 \hat{\gamma} \rightarrow(\mathrm{B} 10 \times \mathrm{B} 6) \hat{\jmath}$ & + & & \\
\hline $\mathrm{B} 10 \AA \rightarrow(\mathrm{B} 10 \times \mathrm{B} 6) \&$ and $\mathrm{B} 109 \rightarrow(\mathrm{B} 10 \times \mathrm{B} 6)$ ? & + & & \\
\hline $\mathrm{B} 10 \hat{\jmath} \rightarrow(\mathrm{B} 10 \times \mathrm{B} 6)$ ? and $\mathrm{B} 10 \hat{\jmath} \rightarrow(\mathrm{B} 10 \times \mathrm{B} 6) \hat{\sigma}$ & + & & \\
\hline $\mathrm{C}_{3} \mathrm{H}_{\delta} \rightarrow(\mathrm{B} 6 \times \mathrm{C} 3 \mathrm{H})+$ and $\mathrm{C} 3 \mathrm{H}+9 \rightarrow(\mathrm{B} 6 \times \mathrm{C} 3 \mathrm{H})$ 우 & + & & \\
\hline $\mathrm{B} 10 \hat{\beta} \rightarrow(\mathrm{B} 10 \times \mathrm{C} 3 \mathrm{H})+$ and $\mathrm{B} 109 \rightarrow(\mathrm{B} 10 \times \mathrm{C} 3 \mathrm{H})$ 웅 & & + & \\
\hline $\mathrm{B} 10 \hat{\jmath} \rightarrow(\mathrm{B} 10 \times \mathrm{C} 3 \mathrm{H}) \propto$ a and $\mathrm{B} 10 \hat{\jmath} \rightarrow(\mathrm{B} 10 \times \mathrm{C} 3 \mathrm{H}) \hat{\jmath}$ & + & & \\
\hline 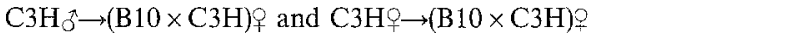 & + & & \\
\hline $\mathrm{C} 3 \mathrm{H}_{\delta} \rightarrow(\mathrm{B} 10 \times \mathrm{C} 3 \mathrm{H})$ ? and $\mathrm{C} 3 \mathrm{H}_{0} \rightarrow(\mathrm{B} 10 \times \mathrm{C} 3 \mathrm{H}) \hat{\jmath}$ & + & & \\
\hline $\mathrm{B} 10 \hat{\jmath} \rightarrow(\mathrm{DBA} / 2 \times \mathrm{B} 10) 9$ and $\mathrm{B} 10 \hat{\sigma} \rightarrow(\mathrm{DBA} / 2 \times \mathrm{B} 10) \hat{\jmath}$ & & & + \\
\hline $\mathrm{DBA} / 2 \hat{\mathrm{j}} \rightarrow(\mathrm{DBA} / 2 \times \mathrm{B} 10)$ 우 and $\mathrm{DBA} / 2 \hat{\mathrm{O}} \rightarrow(\mathrm{DBA} / 2 \times \mathrm{B} 10) \hat{\mathrm{j}}$ & + & & \\
\hline $\mathrm{DBA} / 2 \AA \rightarrow(\mathrm{DBA} / 2 \times \mathrm{B} 10)+$ and $\mathrm{DBA} / 29 \rightarrow(\mathrm{DBA} / 2 \times \mathrm{B} 10)$ & + & & \\
\hline 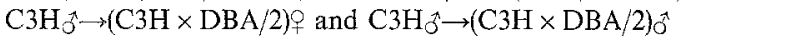 & & & + \\
\hline $\mathrm{B} 10 \AA \rightarrow(\mathrm{B} 10 \times \mathrm{C} 3 \mathrm{H} . \mathrm{SW})$. & + & & \\
\hline $\mathrm{B} 10 \delta \rightarrow(\mathrm{B} 10 \times \mathrm{C} 3 \mathrm{H} . \mathrm{SW})$ 早 and $\mathrm{B} 10 \% \rightarrow(\mathrm{B} 10 \times \mathrm{C} 3 \mathrm{H} . \mathrm{SW}) \hat{\sigma}$ & & & + \\
\hline 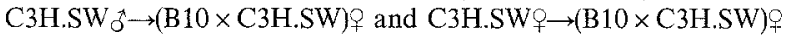 & + & & \\
\hline $\mathrm{C} 3 \mathrm{H} . \mathrm{SW} \zeta \rightarrow(\mathrm{B} 10 \times \mathrm{C} 3 \mathrm{H} . \mathrm{SW})$ q and C3H.SW $\rightarrow(\mathrm{B} 10 \times \mathrm{C} 3 \mathrm{H} . \mathrm{SW}) \delta$ & + & & \\
\hline $\mathrm{C} 3 \mathrm{H} . \mathrm{SW} \sigma \rightarrow(\mathrm{B} 10 \times \mathrm{C} 3 \mathrm{H} . \mathrm{SW}) \mathrm{q}$ and $\mathrm{C} 3 \mathrm{H} . \mathrm{SW} \rightarrow(\mathrm{B} 10 \times \mathrm{C} 3 \mathrm{H} . \mathrm{SW}) \hat{\circ}$ & + & & \\
\hline $\mathrm{C} 3 \mathrm{H}+(\mathrm{B} 10 \times \mathrm{C} 3 \mathrm{H})$ \% and $\mathrm{C} 3 \mathrm{H}_{\sigma} \rightarrow(\mathrm{B} 10 \times \mathrm{C} 3 \mathrm{H}) \mathrm{\sigma}^{\lambda}$ & & + & \\
\hline $\mathrm{C} 3 \mathrm{H}_{+} \rightarrow\left(\mathrm{B} 10 \times \mathrm{C} 3 \mathrm{H}_{0}{ }_{0}\right.$ and $\mathrm{C} 3 \mathrm{H}_{3} \rightarrow(\mathrm{B} 10 \times \mathrm{C} 3 \mathrm{H})_{\hat{\sigma}}$ & & & + \\
\hline
\end{tabular}

donor for the combination, and whether one of the groups being compared is a male-to-female graft.

\section{Discussion}

We had previously found (DeMott-Friberg et al. 1979) that male-to-female syngeneic liver-to-kidney grafts were rejected within 35 days in the $\mathrm{B} 10\left(H-2^{b}\right)$ strain and 140 days in the $\mathrm{B} 6\left(H-2^{b}\right)$ strain. $\mathrm{C} 3 \mathrm{H}\left(H-2^{k}\right)$ and DBA $/ 2\left(H-2^{d}\right)$ male-to-female 
grafts, while showing some degree of immunological reactivity 140 and 70 days after grafting, respectively, survived indefinitely. Skin-grafting studies in congenic lines and recombinants (Bailey and Hoste 1971, Gasser and Silvers 1971, Bailey 1971, Stimpfling and Reichert 1971) showed that the $H-2^{b}$ haplotype carries immune response genes that confer ability to respond to the $\mathrm{H}-\mathrm{Y}$ antigenic determinant. In other skin-graft studies, Silvers and Billingham (1967) reported that the variable survival of male skin grafts in females of different strains resulted from strain dependent differences in the recipient's immune response. However, skin-graft studies in $F_{1}$ animals (Wachtel et al. 1973) indicated that the $H-2$ type of the donor affected expression of the H-Y antigen.

In these studies of male-to-female liver grafts, both strain-dependent expression of $\mathrm{H}-\mathrm{Y}$ and differences in immune response were noted. Degree of expression of $\mathrm{H}-\mathrm{Y}$ is probably independent of the strain's $H-2$ haplotype and results from qualitative or quantitative differences in $\mathrm{H}-\mathrm{Y}$ itself or in modifying genes not linked to $\mathrm{H}-2$. Thus the $H-2$ haplotype of the cell presenting $\mathrm{H}-\mathrm{Y}$ does not affect liver allograft survival in the same way that $\mathrm{H}-2-\mathrm{H}-\mathrm{Y}$ interaction has been shown to affect immune response in other immunological systems (reviewed by Simpson 1982). DeMott-Friberg and co-workers (1979) reported that $\mathrm{C} 3 \mathrm{H}\left(H-2^{k}\right)$ male-to-female liver grafts were not rejected at 70 days after grafting, but C3H.SW $\left(\mathrm{H}-2^{b}\right)$ male-tofemale grafts were rejected. Since both of these strains carry the same $\mathrm{H}-\mathrm{Y}$ antigen but differ in $H-2$, the difference in survival of male-to-female liver grafts could be attributed either to interaction of $H-2$ and $\mathrm{H}-\mathrm{Y}$ on donor liver cells or to differences in the immune response of recipients bearing the $H-2^{k}$ and the $H-2^{b}$ haplotypes. The present studies show that both $(\mathrm{B} 6 \times \mathrm{C} 3 \mathrm{H}) \mathrm{F}_{1}$ and $(\mathrm{B} 10 \times \mathrm{C} 3 \mathrm{H}) \mathrm{F}_{1}$ females reject $\mathrm{C} 3 \mathrm{H}$ male liver grafts and that C3H.SW male liver grafts are also rejected by (B10 $\times \mathrm{C} 3 \mathrm{H}$.SW) $\mathrm{F}_{1}$ females. These data indicate that strong $\mathrm{H}-\mathrm{Y}$ antigens are expressed on both $\mathrm{C} 3 \mathrm{H}$ and $\mathrm{C} 3 \mathrm{H}$.SW male liver but that the immune response to these antigens in $H-2^{k}$ females differs from the response of $H-2^{b}$ females or $H-2^{k} / H-2^{b}$ females.

Responses to grafts of $\mathrm{B} 6$ and $\mathrm{B} 10$ male liver in $\mathrm{F}_{1}$ female recipients differed from responses in $\mathrm{B} 6$ and $\mathrm{B} 10$ female recipients (Table 1). $(\mathrm{B} 10 \times \mathrm{C} 3 \mathrm{H}) \mathrm{F}_{1}$ female recipients rejected $\mathrm{B} 10$ male grafts but less vigorously than either $(\mathrm{B} 10 \times \mathrm{B} 6) \mathrm{F}_{1}$ female recipients $(.025<\mathrm{p}<.1)$ or $\mathrm{B} 10$ female recipients (DeMott-Friberg et al. 1979). Also $(\mathrm{B} 6 \times \mathrm{C} 3 \mathrm{H}) \mathrm{F}_{1}$ female recipients rejected their $H-2^{b}$ parental male grafts much less vigorously than $\operatorname{did}(\mathrm{B} 10 \times \mathrm{B} 6) \mathrm{F}_{1}$ females $(\mathrm{p}<.01)$ or $\mathrm{B} 6$ female recipients (DeMott-Friberg et al. 1979). The response to the H-Y antigen of both B10 and B6 liver is altered by the presence in the recipient of either the $H-2^{k}$ of the $\mathrm{C} 3 \mathrm{H}$ parent or non- $H-2$ genes that modify the immune response and that are present in $\mathrm{C} 3 \mathrm{H}$. Since the response to $\mathrm{B} 10$ male liver grafts in $(\mathrm{B} 10 \times \mathrm{C} 3 \mathrm{H}$.SW $) \mathrm{F}_{1}$ female recipients is less vigorous than the response found in $\mathrm{B} 10$ female recipients, suppression of response to $\mathrm{B} 10$ liver in the $(\mathrm{C} 3 \mathrm{H}$ or $\mathrm{C} 3 \mathrm{H} . \mathrm{SW} \times \mathrm{B} 10) \mathrm{F}_{1}$ is not due to genes of the $\mathrm{H}-2$ complex. The suppressive effect in these combinations must be due to modification of the immune response by non- $H-2$ genes.

Although B6-male-to-B6-female grafts survived longer (140 days) than B10male-to-B10 female grafts (35 days) (Schultz et al. 1982), B6 male grafts were rejected as vigorously or slightly more vigorously than $B 10$ male grafts by $(B 6 \times B 10) F_{1}$ female recipients. These data further support the hypothesis that there are immune 
response genes not linked to $H$-2 that influence the survival time of a male-to-female liver graft. These genes are responsible for different immune responses to the H-Y antigen in B10 females, B6 females and $(\mathrm{B} 10 \times \mathrm{B} 6) \mathrm{F}_{1}$ hybrid females.

von Boehmer and co-workers (1978) have hypothesized that the tissue type of the thymus in which T-cell subpopulations differentiate influences the response to the H-Y antigen. This hypothesis, which is based on CML data, is consistent with our in vivo data. The results shown here point to suppression in $F_{1}$ animals that could result from differentiation processes unique to the $F_{1}$. These changes in extent of suppression may be translated into anti-H-Y response that differ from parental responses. Moreover, the genetic focus of immunocompetent cell alterations does not appear to reside in the $\mathrm{MHC}$.

$(\mathrm{DBA} / 2 \times \mathrm{B} 10) \mathrm{F}_{1}$ females also show less immune reaction to grafts from $\mathrm{B} 10$ male liver donors (Table 1 ) than do B10 females. In this case either non- $\mathrm{H}-2$ modifying genes of the DBA/2 $\left(H-2^{d}\right)$ female or a unique immune response to genes formed from the hybridization of $I$ region genes of the $H-2^{d}$ and $H-2^{b}$ haplotypes may act to reduce the immune response to the $\mathrm{B} 10$ male liver graft. The absence or reduced expression of $\mathrm{I}^{\mathrm{b}}$ specificities Ia.8 and Ia.9 in the $\left(\mathrm{I}^{\mathrm{b}} \times \mathrm{I}^{\mathrm{k}}\right) \mathrm{F}_{1}$ combination has recently been reported (Sandrin et al. 1981). LaFuse and co-workers (1980) have also reported the appearance of hybrid Ia specificities in $\mathrm{F}_{1}$ mice. These specificities arise from combinations between subunits coded for by the $I A$ and $I E$ regions of two different $H$-2 haplotypes. The results of Wicker and Hildemann (1981) indicate that the presence of hybrid molecules in $F_{1}$ recipients may enhance or reduce the immune response of $F_{1}$ animals to synthetic antigens. Simpson and Gordon (1977) cite $I r$ gene complementation as a possible explanation for anti-H-Y reactivity in vitro in $\mathrm{F}_{1}$ hybrids.

Neither $H-2^{d}$ or $H-2^{k}$ females are responders to the H-Y antigen in the livergrafting system used in these studies. Female $H-2^{d} / H-2^{k}$ animals are also unresponsive to male parental grafts since $(\mathrm{C} 3 \mathrm{H} \times \mathrm{DBA} / 2) \mathrm{F}_{1}$ females failed to react to male grafts (Table 1 ). Therefore combining the $\mathrm{C} 3 \mathrm{H}$ and $\mathrm{DBA} / 2$ genomes into a single $\mathrm{F}_{1}$ does not cause any change in the anti-H-Y immune response found in the $\mathrm{C} 3 \mathrm{H}$ or $\mathrm{DBA} / 2$ inbred strains.

We conclude from these studies that the $\mathrm{H}-\mathrm{Y}$ antigen, which is expressed on liver celis (DeMott-Friberg et al. 1979), evokes an immune response in $F_{1}$ mice. It appears that the strengths or concentrations of $\mathrm{H}-\mathrm{Y}$, or both, differ on liver cells of different strains, with the $\mathrm{H}-\mathrm{Y}$ immune potential of $\mathrm{C} 3 \mathrm{H}>\mathrm{B} 10>\mathrm{DBA} / 2$. Similar differential expression of $\mathrm{H}-\mathrm{Y}$ has been described in skin and the thymus (Králová and Démant 1976). Response to the H-Y is greatest in the $H-2^{b}$ haplotype but this response may be modified by the concomitant presence in the recipient of the $H-2^{d}$ or $H-2^{k}$ nonresponder haplotype, or by non- $H-2$ genes of the $\mathrm{C} 3 \mathrm{H}$ or DBA/ 2 strain. It is possible that hybrid immune response antigens are responsible for the alteration in response seen in some $F_{1}$ hybrid mice. An alternate explanation for the finding that $F_{1}$ immune response to liver grafts differs from that of either parental is the difference in functional characteristics of the immunocompetent cell populations of $F_{1}$ hybrids and parentals. This variation may be due to the presence of nonparental receptor sites on immunocompetent cells or to the $F_{1}$ thymic environment in which the cells have differentiated. 
Acknowledgments. This study was supported by the Medical Research Service of the Veterans Administration. The authors thank Mary Bouwsma and Marilyn Marlowe for excellent technical assistance and Icey Heningberg and Delores Hooks for typing the manuscript. Thanks are also due to Drs. Rane Curl and Jerome Schultz for their advice on statistical methods.

\section{References}

Bailey, D. W.: Allelic forms of a gene controlling the female immune response to the male antigen in mice. Transplantation 11: 426-428, 1971

Bailey, D. W. and Hoste, $\mathrm{J}$ : A gene governing the female immune response to the male antigen in mice. Transplantation 11: 404-407, 1971

Cudkowicz, G. and Bennett, M.: Peculiar immunology of bone marrow allografts. II. Rejection of parental grafts by resistant $F_{1}$ hybrid mice. J. Exp. Med. 134: 1513-1528, 1971

DeMott-Friberg, R., Beals, T. F., and Schultz, J. S.: $H$-2 and background influences on tissue grafts across the H-Y barrier. Immunogenetics 9: 369-381, 1979

Eichwald, E. J., Wetzel, B., and Lustgraaf, E. C.: On the hybrid effect in skin grafting. Transplantation 3: $764-766,1965$

Gasser, D.L. and Silvers, W. K.: Genetic control of the immune response in mice. III. An association between $H-2$ type and reaction to H-Y. J. Immunol. 106: 875-876, 1971

Gasser, D. L. and Silvers, W. K.: Genetics and immunology of sex-linked antigens. Adv. Immunol. 15: 215-247, 1972

Hellström, K. E.: Growth inhibition of sarcoma and carcinoma cells of homozygous origin. Science 143 : $477-478,1964$

Králová, J. and Démant, P.: Expression of the H-Y antigen on thymus cells and skin: differential genetic control linked to $K$ end of $H-2$. Immunogenetics 3: 583-594, 1976

LaFuse, W.P., McCormick, J. F., and David, C. S.: Serological and biochemical identification of hybrid Ia antigens. J. Exp. Med. 151: 709-715, 1980

Mood, A. M.: Introduction to the Theory of Statistics, McGraw Hill, New York, 1950

Nakano, K., Nakamura, I., and Cudkowicz, G.: Generation of $F_{1}$ hybrid cytotoxic $T$ lymphocytes specific for self $\mathrm{H}-2$. Nature 289; 559-563, 1981

Sandrin, M. S., Tobias, G. H., McKenzie, I. F. C., and Hämmerling, G. J.: Alterations in the Expression of Ia Antigens in $\mathrm{F}_{1}$ hybrid mice. Immunogenetics 14: 507-516, 1981

Schultz, J. S., Beals, T. F., and Petraitis, F. P.: Tissue graft rejection in mice. I. Contributions of $H-2$ and non- $\mathrm{H}-2$ genetic barriers. Immunogenetics 3: 85-96, 1976

Schultz, J.S., Beals, T. F., and DeMott-Friberg, R.: Tissue graft rejection in mice. V. Survival, rejection, or proliferation across minor barriers. Immunogenetics 6: 585-595, 1978

Schultz, J. S., DeMott-Friberg, R., and Beals, T. F.: Immunogenetic control of the response of female mice to male tissue grafts. Immunogenetics 12: 199-205, 1981

Schultz, J.S., DeMott-Friberg, R., and Beals, T.F.: Liver tissue graft rejection in murine major histocompatibility complex mutants. Immunogenetics $15: 357-364,1982$

Silvers, W. K. and Billingham, R. E.: Genetic background and expressivity of histocompatibility genes. Science 158: 118-119, 1967

Silvers, W. K. and Wachtel, S. S.: $H$-Y antigen: behavior and function. Science 195: 956-960, 1977

Simpson, E.: The role of H-Y as a minor transplantation antigen. Immunol. Today 3: 97-106, 1982

Simpson E. and Gordon, R. D.: Responsiveness to $H$-Yantigen, $I r$ gene complementation and target cell specificity. Immunol. Rev. 35: 59-75, 1977

Simpson, E., McLaren, A., and Chandler, P.: Evidence for two male antigens in mice. Immunogenetics 15 : $609-614,1982$

Snell, G. D.: Histocompatibility genes of the mouse. I. Demonstration of weak histocompatibility differences by immunization and controlled tumor dosage. J. Natl. Cancer Inst. 20: 787-824, 1958

Stimpfling, J. H. and Reichert, A. E.: Male-specific graft rejection and the $H-2$ locus. Transplantation 12 : $527-531,1971$

von Boehmer, H., Haas, W., and Jerne, N.K.: Major histocompatibility complex-linked immuneresponsiveness is acquired by lymphocytes of low-responder mice differentiating in thymus of high-responder mice. Proc. Natl. Acad. Sci. U.S.A. 75: 2439-2442, 1978 
Wachtel, S. S., Gasser, D. L., and Silvers, W. Y.: Male-specific antigen: modification of potency by the H-2 locus in mice. Science 181: 862-863, 1973

Wicker, L. S. and Hildemann, W. H.: Two distinct high immune response phenotypes are both controlled by $H-2$ genes mapping in $K$ or $I-A$. Immunogenetics $12: 253-265,1981$

Received August 13, 1982; revised version received January 12, 1983 